\title{
Toronto municipal staff and policy-makers' views on urban agriculture and health: A qualitative study
}

\author{
Special JAFSCD Issue \\ Local Government in Food Systems Work \\ Sponsored by \\ GROWING FOOD \\ CONNECTIONS
}

\author{
Kate Mulligan a and Josephine Archbold b \\ Healthy Public Policy Division, City of Toronto \\ Lauren E. Bakerc \\ Food Policy Council, City of Toronto \\ Sarah Elton ${ }^{\mathrm{d}}$ and D onald C. Cole $\mathrm{e}^{*}$ \\ D alla Lana School of Public Health, University of Toronto
}

Submitted November 13, 2017 / Revised January 6 and January 31, 2018 / Accepted February 2, 2018 /

Published online O ctober 17, 2018

Citation: Mulligan, K., Archbold, J., Baker, L. E., Elton, S., \& Cole, D . C. (2018). Toronto municipal staff and policy-makers' views on urban agriculture and health: A qualitative study. Journal of A griculture, F ood Systems, and Community D evelopment, 8(Suppl. 2), 133-156. https:/ / doi.org/ 10.5304/ jafscd.2018.08B.001

Copyright (c) 2018 by the Authors. Published by the Lyson Center for Civic Agriculture and Food Systems. Open access under CC BY license.

\begin{abstract}
Municipal governments across the $\mathrm{G}$ lobal North are increasingly becoming key actors in shaping urban food and agriculture policy. In the City of Toronto, recent aspirational policies, such as the provincial Local Food Act and the municipal

a Kate Mulligan, Director, Policy \& Communications, Association of O ntario Health Centres; 970 Lawrence Avenue West, Suite 500; Toronto, Ontario M6A 3B6 Canada; +1-416236-2539 x244; kate.mulligan@ aohc.org; also Assistant Professor, Social \& Behavioural Health Sciences, D alla Lana School of Public Health, University of Toronto; kate.mulligan@utoronto.ca

b Josephine Archbold, City Clerk's O ffice, City of Toronto; City Hall, 12th Floor, West Tower 100 Queen Street West; Toronto ON M5H 2N2 Canada; +1-416-392-8088; Josephine.archbold@toronto.ca

c Lauren E. Baker, Adjunct Professor, Equity Studies, New College, University of Toronto; le.baker@utoronto.ca; and Research Associate, Ryerson Centre for Studies in Food Security, Ryerson University; and Food Systems Consultant (https:/ / laurenbaker.ca/)
\end{abstract}

Toronto Agricultural Program, created new opportunities to shape a healthier food system. We sought municipal perspectives on the question of "How might urban agriculture policy and programs be better supported to promote equity and health?" Analysis of findings from semistructured key

\footnotetext{
d Sarah Elton, Ph.D . student, D alla Lana School of Public Health, University of Toronto; 155 College Street, Room 508; Toronto, ON M5T 3M7 Canada.

e * Corresponding author: Professor D onald C. Cole, D alla Lana School of Public Health, University of Toronto, Room 584 Health Sciences Building, 155 College Street; Toronto, ON M5T 3M7 Canada; +1-416-946-7870; donald.cole@utoronto.ca
}

\section{Disclosures}

Kate Mulligan, Josephine Archbold, and Lauren Baker were active in food policy, urban agriculture and health work as staff of the City of Toronto during the research. Josephine Archbold and D onald Cole were members of the Healthier Harvests Consortium, which gestated the research. The Healthy Public Policy Division of Toronto Public Health contracted Sarah Elton and D onald Cole to provide assistance in write-up for publication. 
informant interviews with municipal staff and policy-makers $(n=18)$ illustrated broad support for generating better quantifiable evidence of the impacts of urban agriculture on economic development and employment, health and health equity, land use and production, and partnerships and policies. Place-specific economic and equity data emerged as particularly pressing priorities. At the same time, they sought better approaches to the potential risks involved in urban agriculture. Key informants also shared their views on the use of health impact assessment research to make a case for urban agriculture to a range of stakeholders; to manage real and perceived risks; and to move beyond enabling policies to empower new investments and procedural changes that would facilitate urban agriculture expansion in the city. The results informed the evolving praxis agenda for urban agriculture at the intersections of population health, environmental sustainability, and urban governance.

\section{Keywords}

Urban Agriculture; D eterminants Of Health; Healthy Public Policy; Indicators; Livelihoods; Urban Renewal; Resilience; Municipal G overnance; Knowledge Exchange; Canada

\section{Introduction and Literature Review}

In recent decades, cities have emerged as leading food policy actors on a scene previously dominated by national and global policy regimes (Morgan, 2015; Tornaghi, 2014). Urban governments of the global North have been addressing the current global food crisis with municipal-level responses, such as creating new food policy councils, crafting integrative strategies that focus on the broader city region (Blay-Palmer, Renting, \& D ubbeling, 2015; Raja, Morgan, \& Hall 2017), and implementing interconnected interventions (Sonnino, 2013). Among policy and program options, urban agriculture (UA) - activities connected with the growing, processing, and distribution of food and foodrelated products in and around cities- has experienced something of a revival (Ikerd, 2017). Planning facilitation, ordinance changes, and program supports to UA practitioners have been considered and/ or implemented in many North American and
European cities (Boston, 2017; Forster, Egal, Renting, D ubbeling, \& Escudero, 2015). For example, one of the recommended actions (\#20) in the Milan Urban Food Policy Pact (Milan UFPP; Forster et al., 2015, p. 4) was to "promote and strengthen urban and peri-urban food production and processing based on sustainable approaches and integrate urban and peri-urban agriculture into city resilience plans."

Cities, A griculture and $\mathrm{H}$ ealth Among the potential benefits associated with such efforts, urban agriculture's influence on the social and environmental determinants of urban health has been prominent (Beckie \& Bogdan, 2010; Cole, Grace, \& Diamond, 2008; Guitart, Pickering, Byrne, 2012; Kortright \& Wakefield, 2011; McCormack, Laska, Larson, \& Story, 2010). Urban agriculture activities at different scales and settings- from backyard food growing, to community food gardens in city parks, to rooftop gardens on institutional buildings, to urban farms - can increase food security in equity enhancing ways. UA can, at least seasonally, provide relatively low cost, nutritious, culturally resonant, and diverse foods among immigrant-refugee populations and in low income neighbourhoods (Armstrong, 2000; Baker, 2002; Brown \& Jameton, 2000; Meenar \& Hoover, 2012; Wegener, Hanning, \& Raine, 2012a, 2012b; White 2011), though not universally (McClintock, 2014; Warren, Hawkesworth, \& Knai, 2015). Improved food literacy (Vidgen \& Gallegos, 2011) and increased physical activity (D raper \& Freedman, 2010) have also been noted. Indirect health benefits can occur by improving the integration of community-building, increasing social cohesion across ages and cultures, and bolstering solidarity by sharing produce and other forms of assistance (Baker, 2004; Cabannes \& Raposo, 2013; Holland, 2004; Kingsley \& Townsend, 2006; Wakefield, Y eudall, Taron, Reynolds, \& Skinner, 2007). Finally, with climate change, UA can reduce carbon footprints in large urban centers (Pearson, Pearson, \& Pearson, 2010). As Ikerd (2017) noted, "the urban agriculture movement is as much about restoring urban quality of life as improving urban food security" (p. 15). Because UA's social and environmental interventions potentially promote 
equity and sustainability, as well as individual health and well-being, they represent potentially important population health interventions in urban areas.

\section{Challenges in Implementation}

Yet realizing such potential benefits of UA beyond demonstration projects has been challenging (McClintock, 2014), often getting caught in the complex web of urban governance (Brand et al., 2017; Gore, 2008; Reynolds \& Cohen, 2016). This evolving policy and practice environment, in which actors rely on social partnerships and knowledge transfer between community, public, private, and not-for-profit actors operating at different scales, is not well understood. Municipal food policy can respond to civil society and develop from multisectoral initiatives within local government (Prain, Lee-Smith, \& Cole, 2008; Wegener et al., 2012a, 2012b).

However, promoting urban agriculture as part of shifting food systems to address inequities in broad determinants of health, livelihoods and urban sustainability can often be challenging ( $\mathrm{G}$ ore, 2008). For example, in Flint, Michigan, civil society actors faced city ordinances that neither matched nor facilitated current or potential UA activities (Masson-Minock \& Stockmann, 2010). They organized themselves and engaged the public over an extended period to demand that the Flint City Planning Commission regularize a variety of smallscale food production; this effort was only partially successful. Similarly, the $\mathrm{O}$ akland Food Policy Council (OFPC) recognized zoning "as an obstacle to UA's expansion" (McClintock, Wooten, \& Brown, 2012). They developed broader food systems goals first, in order to garner buy-in of city officials, before focusing on new zoning definitions and operating standards for UA. Land use and zoning decisions remain a crucial area of municipal control, with considerable bureaucratic effort applied to them. However, they are also an arena of substantial contestation for powerful development lobbies and those interested in making land more accessible to marginalized groups in order to promote greater equity. In addition, municipal staff and policy-makers are challenged to choose among the numerous options for municipal initiativessuch as the multitude of recommendations in the
MUFPP - often with incomplete information. Hence, considerable work has gone into UA relevant indicators. These include indicators of need for or inequity potentially addressed by different food security or UA approaches (Meenar, 2017). The likely impads of particular initiatives have been synthesized through either literature summaries or full impact assessments (health or environmental) (Cowling, Lindberg, D annenberg, Neff, \& Pollack, 2017). M etrics or monitoring data from pilots or development projects are also potentially helpful to better understand the implementation of municipal UA initiatives (Cohen, Reynolds, Sanghvi, \& Chou, 2012). In dynamic municipal policy and program environments, each of these kinds of indicators might be important for informing decision-making, but, in most cases, they are lacking. Hence, Sonnino argued the need for applied research that can support k nowledge building "by providing data... that help planners and policy makers to understand the functioning of the urban food system" (2009, p. 433).

\section{Tensions A round UA Promotion as Part of L ocal F ood Systems}

Writings on the promise of urban agriculture for the promotion of equity exceed those of rigorous case studies documenting such promotion at the municipal level (Meenar, 2017). Q uestions remain as to how UA is conceptualized among municipal staff and policy-makers. In particular, how do they understand and navigate, as Tornaghi (2014) writes, "the intermingling of (and sometimes tension between) leisure and economical needs, mental benefits and physical health, environmental ethics and social justice principles, their food preferences and environmental 'aesthetics'"? (2014, "The blurred line," para. 1). In particular, to what extent do staff and policy-makers see historical equity concerns as central? (Clark, Freedgood, Irish, Hodgson, \& Raja, 2017). D o they think that UA promotion should involve targeted programs primarily for the vulnerable (e.g., subsidized food production by those with mental health conditions); universal approaches (e.g., zoning bylaw changes for a greener city); or proportionate universalist approaches (e.g., expansion of available community gardening plots to be able to respond to all those with 
household food security challenges) (NCCD H 2013)? Challenges in implementation may also belie fundamentally different conceptions of municipal mandates, with respect to UA, versus those of other governmental levels. For example, around soil contamination in brownfield areas, often several levels of government-from provincialstate, through federal, to international standardsmay be involved in either prohibiting the use of certain land to grow food or guiding clean up (TPH, 2011).

Further, most food consumed in large metropolitan areas comes from regional or global sources (McRae, G allant, Patel, Michalak, Bunch, \& Schaffner, 2010). Cities often brand themselves as projecting regionally, nationally, and globally, which exacerbates tensions associated with scale. With multiple sectors and levels involved in conceptualizing a 'local' or 'city-region' food system, staff must grapple with a huge range of dominant players in the food system at a much larger scale (Clapp, D esmarais, \& Margulis, 2015).

In this paper, we locate these tensions in the context of food policy developments in one city in the global North (Toronto, Ontario, Canada). We first outline our approach to seeking the views of municipal staff and policy-makers on the question of "How might urban agriculture policy and programs be better supported to promote equity and health"? We then share our findings, subsequent developments, and their implications for municipal departments working on urban food systems planning.

\section{City of Toronto Context}

At the municipal level, the Toronto Food Policy Council (TFPC) was the first in North America (Blay-Palmer, 2009), spearheading the development of the Toronto Food Strategy (Toronto Food Policy Council, 2010). In Toronto, a vibrant community of farmers, land owners, not-for-profit organizations, and food activists from diverse communities (of colour, origin, and socioeconomic status) has pursued opportunities for urban agriculture in spite of legislative and policy uncertainties (see Box 1, Timeline).

Early work documented the activities and impacts of a small sample of community gardens
(Baker, 2002). This was followed by broader attempts to estimate the potential contribution of vegetable production in the city to its food needs (MacRae, Gallant, Patel, Michalak, Bunch, \& Schaffner, 2010) and to strategize around scaling up UA (Nasr, MacRae, \& Kuhns, 2010). Early on, Toronto Public Health (TPH) staff played a leading role among municipal departments. It also met traditional public health mandates by developing a guide to deal with soil contamination (TPH, 2011; TPH, 2013).

With a strong push from food activists, nongovernmental organizations (Saul \& Curtis 2013), farmers, and gardeners, in collaboration with various city divisions and agencies, the possibilities for the advancement of UA expanded with the ground-breaking report titled $\mathrm{G}$ rowT 0 : an urban agriculture action plan for Toronto (City of Toronto, 2012). In November 2013, the City of Toronto adopted the T oronto A griaultural Program (TAP), an ambitious work plan to advance UA with the development of data to support the rapid expansion of urban agricultural hubs and related programs within the City of Toronto (2013). At the same time, the city council established a Joint CitySector Steering Committee on Urban Agriculture, directed city staff to explore the removal of policy barriers to urban land use and food entrepreneurship, and sought advice on the establishment of one or more urban agricultural centres. Municipal support has also included the city public health department nurses involved in school gardens; cityfunded Live Green Toronto Parks grants and educational and/ or outreach materials; Parks, Forestry, and Recreation Community G arden and Children's Garden programs; exploration of the world crops that could be grown to feed immigrant communities (Vineland Research and Innovation Centre, Toronto Food Policy Council, \& TPH, 2013); and support for funding applications to foundations and provincial funders like the O ntario Ministry of Agriculture and Food.

Changes in UA policy and practice at Canadian municipal, regional, provincial, and federal levels set out an ambitious agenda for further policy change and community action over the coming years. The provincial L ocal F ood A ct, for example, aims among other things to "to foster successful 
Journal of Agriculture, Food Systems, and Community Development

Box 1. Timeline of Dates Relevant to Urban Agriculture for Toronto, Ontario, Canada

1990 Toronto Food Policy Council was formed.

1993 Interdepartmental collaboration at the City leads to the creation of the report: "Supports for Urban Food Production: Creating a Garden City 1997." Community Gardens Program Coordinator position created in the Parks, Forestry, and Recreation Division of the City.

1999 City Council endorses the Community Garden Action Plan, which sets the goal of establishing a community garden in every ward of the city.

2001 City of Toronto Food and Action Hunger Committee releases "The Growing Season" report, which recommends that the City step up to become a champion for food security, through actions such as promoting urban agriculture and enumerating its benefits for Toronto.

2001 Through the adoption of the Toronto Food Charter, City Council commits to supporting community gardening and urban agriculture in the interest of increased food security in the city.

2004 Toronto hosts the American Community Gardening Association annual conference.

2004 City of Toronto partners with Toronto and Region Conservation Authority (TRCA) to create the Toronto Urban Farm at Black Creek Pioneer Village.

2005 The Toronto Community Food Animators program, a partnership between The Stop, FoodShare, Afri-Can Food Basket, and Second Harvest, is funded through the City's Community Partnership and Investment Program.

2006 Toronto's Official Plan expresses support for community and rooftop gardens as important elements for creating beautiful, healthy and active cities and for engaging diverse communities.

2006 The City supports Toronto District School Board (TDSB) research on market gardens.

2007 Toronto Community Housing (TCH) publishes a "Community Gardening Manual."

2008 Toronto and Region Conservation Authority (TRCA) introduces a progressive Sustainable Near-Urban Agriculture Policy.

2009 City Council adopts the report: "Identifying Urban Agriculture Opportunities in the City of Toronto," affirming the City's support for strategies and initiatives that achieve the overall goal of expanding opportunities for local food production in Toronto.

2010 The Toronto Food Strategy led by Toronto Public Health outlines a vision for a healthy sustainable food system for Toronto through the Cultivating Food Connections report.

2011 - The City of Toronto Environment Office supports the GrowTO Speaker Series and publishes the booklet "Get Growing Toronto: A Guide to Growing Food in the City."

2011 Toronto Public Health develops a soil assessment guide to assist urban gardeners in determining soil safety.

2012 City Council approves the Greater Golden Horseshoe Food and Farming Action Plan, which promotes the preservation of farmland in Ontario as well as the expansion of urban opportunities to produce food.

2012 Toronto hosts the first International Urban Agriculture Summit

2012 GrowTO: An Urban Agriculture Action Plan for Toronto developed and endorsed by council

2013 Toronto Agriculture Program created by Toronto City Council

and resilient local food economies and systems throughout Ontario" (Ontario, 2013, p. 1). It directs the provincial government and designated public sector organizations to establish targets related to local food production and food literacy. At the federal level, UA is one of the key pillars of Rouge Park, the first Canadian national park in an urban space (Toronto Region Conservation Authority, 2013).

In addition, there has been institutional openness to equity discourse at the City of Toronto.
Toronto Public Health has health equity as a foundational principle and part of its mission: "Toronto Public Health reduces health inequities and improves the health of the whole population" (TPH, n.d.). Citywide initiatives include the Poverty Reduction Strategy (City of Toronto 2015), in which food access is a key component, and the Tower Renewal Program, which promotes market gardens around residential towers as part of revised Residential A partment Commercial zoning. Both are examples in which community organizations 
and activist councillors worked with municipal staff to develop concrete responses for racialized, lowincome, and otherwise marginalized communities. Such initiatives have necessarily involved TPH engagement with other municipal sectors and a broad range of stakeholders in order to promote healthy urban planning and public policy.

$\mathrm{H}$ ealthier $\mathrm{H}$ arvest $\mathrm{C}$ onsortium As researchers in Toronto Public Health's Healthy Public Policy D irectorate (Archbold and Mulligan) and Toronto Food Policy Council (Baker), we convened the Healthier Harvest Research Consortium in May 2013. We were a collective of Toronto-based researchers from academic, public health, and community-based organizations striving to bolster the evidence needed for scaling up UA as part of changes required in Toronto's food system. Through our diversity of experiences working across sectors and jurisdictions, we knew that staff and policy-makers involved in shaping Toronto's policy agenda would likely have varying views on UA and that it would be grounded in their position within municipal or other structures, their fields of study, social locations, and personal experiences.

We particularly sought insights regarding useful and simple-to-communicate indicators which could be used to measure and document the ways UA supports equity, poverty reduction, sustainability, and health promotion goals in the policypractice dynamic they experienced. At the same time, we saw it as an opportunity to both contextualize such work in the municipal policy landscape and engage in knowledge exchange around operational feasibility, barriers, and opportunities for the growth of UA. By engaging with staff as key knowledge-users throughout the research processusing the "integrated knowledge translation" model set out by Barwick (2008, updated 2013) - we aimed to identify the key discourses, lines of evidence, and areas of collective interest that shape the data needs of staff and potential uses by policymakers in the municipal policy process.

\section{Applied Research Methods}

As a research team, we found Colasanti's (2009)

notion of city-scale UA helpful in her conceptual- ization of the ways in which city food growing is mediated by political and economic processes. O ur theoretical stance was closest to the political ecology of urban health framings. We understood human bodies and urban environments as literal, biophysical expressions of social, material, and ecological contexts (Heynen, Kaika, \& Swyngedouw, 2005; Keil, 2005). Further, we recognize that the relationship between humans and the nonhuman living world (e.g., the plants humans grow) is mediated by governance, democracy, and the politics of everyday life (Keil, 2003). Hence, our primary focus was on the conceptualizations and tensions faced in municipal policy-making around UA.

\section{Participants}

Prior to recruitment, our study received ethics approval from the Toronto Public Health Research Ethics Review Board. We then purposively sought out key municipal staff and policy decision makers in urban agriculture for key informant interviews. These included policy-makers working in government and community agencies at the municipal and provincial (O ntario $)^{1}$ levels, as well as farmers, landowners, and funders in the greater Toronto and Hamilton area. Their areas of work ranged from land use planning and conservation to social inclusion and equity. Twenty-seven prospective participants were identified in the policy and practice communities of the authors and the Healthier Harvest Research Consortium. They received a formal letter by email from Toronto Public Health detailing the study's purpose, methods, confidentiality measures, and procedures for informed consent. Recruitment used a maximum variation sampling strategy to provide for a broad range of perspectives. Eighteen people agreed to an interview (18/ 27): four municipal and provincial policymaking staff, four members of not-for-profit organizations at the municipal and provincial levels, four funders, three landowners (public and private), and three farmers.

\footnotetext{
${ }^{1}$ We attempted to interview an individual from the federal government, but no relevant federal departments would agree to an interview.
} 
D ata Collection

Interviews were conducted in person or by telephone between November 2013 and March 2014, lasting approximately 45 minutes. The interviews were semistructured and followed a theoretically and pragmatically driven interview guide (see Appendix). A literature review and consultation with the research team informed the questions. With permission, all interviews were recorded and transcribed.

\section{A nalysis}

We situated our analysis of key informant knowledge, attitudes, and practices within the larger sociocultural and political economic structure of the food system. Further, we followed Barwick's "integrated knowledge translation" model (2008) to identify the dominant discourses, lines of evidence, and areas of collective interest that shape data wants and/ or needs around urban agriculture in a municipal context. The interviews were coded and content analyzed with the assistance of the qualitative analysis software ATLAS.ti 6. Thematic codes, emergent and derived from theoretical and empiric literature, were applied to the interview transcripts and refined throughout the analysis. Reliability of the initial coding and its application to the data were assessed using both qualitative comparison and quantitative tests of inter-rater reliability. O ne internal coder and one external coder applied a set of theory-derived thematic codes to two transcripts while also considering emergent themes using an inductive, grounded approach. The arising themes were qualitatively compared and a high degree of consistency was found between coders. In areas of disagreement between raters, new dialogues emerged and helped to clarify the coding scheme and helped to further identify additional analytical directions. For the final code set, Krippendorff's (2013) Alpha (a measure of inter-coder reliability for three or more coders) was 0.83 .

We sought feedback from respondents at two points during the research process. In some interviews, we summarized responses at the time of the interview to confirm accuracy in understanding. Then, after the interview, the participants were shown a written summary of the key findings and were given the option to comment in writing on the accuracy and completeness of the interview. In ongoing discussion within the research team, and in dialogue with members of the Healthier Harvest Research Consortium, we explored researcher biases and their possible influence on our findings.

However, our study had several limitations: a limited breadth of policy-makers (primarily municipal staff), no politicians, and only a few civil society organizations, such that not all stakeholders relevant to urban food system change through a more fulsome concept of governance were represented (G ore, 2008; Clark et al., 2017). Nevertheless, its scope was appropriate for staff working on policy in a public health department to better understand the context and policy and information priorities of their municipal colleagues. Unfortunately, concerns regarding anonymity meant that we could not clarify the role and sector of each respondent in our findings. We engaged in limited probing of the respondent's views, their context in a globalized city, and the inequities associated with large amounts of resources being generated and funnelled in corporate sectors. These sectors do not systematically make their way to racialized and lowincome groups, or to municipal staff working with them, except through occasional donations for urban greening. Given the strictures on staff in municipal bureaucracies, key informants might have responded quickly that their mandates in current governance structures do not permit such considerations, despite their importance in the global food system (International Panel of Experts on Sustainable Food Systems [IPE S-Food], 2017). Further, the dynamic nature of municipal organizations and politics means that views may have progressed since our data collection, so tracking changes over time would be valuable.

\section{Results}

C onceptualization of U rban A griculture For most key informants, urban agriculture represented a small but growing priority for themselves and others within the city. Urban agriculture in Toronto was perceived to be driven primarily by public interest and by city-building movements from across socioeconomic and geographic divides, 
as one municipal staff person noted: "It's not just in the wealthy neighborhoods but also from farmer's markets actually showing up in very diverse and lower income neighborhoods as well... .It's kind of exciting to have this committee that has got urban and rural people on it and having each of them understand the strength that could be in urban agriculture." Informants shared a broad interpretation of urban agriculture as a multifunctional urban intervention with social, economic, environmental, and health dimensions (Morgan, 2015).

At the regional scale, several key informants noted the intersection of prime agricultural land, an educated workforce, a large supply of fresh water, and an ethnically diverse, high-quality food processing sector as key planks of support for a thriving regional food-based economy. Key informants also noted the steady growth of the food sector, even in times of economic downturn, as one municipal policy staff person noted:

The agriculture and food and food service industries are the largest employer now in Ontario, CA \$34 billion worth of economic activity and also seem to have been fairly resilient to things like global recession etc. where everything else went in the tank. Food continued to grow, albeit a small, steady margin right- $2 \%, 3 \%$...there's a helpful solution there because everybody needs to eat.

Information to $\mathrm{M}$ ake the $\mathrm{C}$ ase for $\mathrm{U}$ rban $\mathrm{A}$ griculture Key informants from a wide range of positions saw evidence-informed decision-making as an important approach to policy-making in the City of Toronto. For example, a government-based respondent said, "We talk a lot about using evidence based information to make decisions so if there's more evidence to support a policy or direction... I think evidence only helps support policy development." A nongovernmental advocate noted, "if we can build some metrics and indicators around the health and the economic and environmental impacts that we can actually make a strong solid case that local food systems are the way to go and urban agriculture certainly can be part of that."
A funder observed, "I think the science is always helpful, it's always a helpful support. Certainly [my organization] depends very heavily on scientific based research to demonstrate why it's important to be doing the things that we're asking proponents of development, for example, to do." As part of the support for evidence-informed decisionmaking, respondents expressed a need for a centralized repository for data and information related to urban agriculture and an interest in understanding and measuring change over time.

However, while most respondents agreed that it is important to have, in the words of one respondent, "supporting health evidence to demonstrate that local connections to agriculture and providing agricultural goods and services has a positive health impact for the people involved," several respondents observed that this was more important in making the case to others rather than within their own organizations. For example, one key informant noted that "beyond the intuitive level and beyond the kind of common sense stuff... I wouldn't say we take a ton of empirical evidence and say we're going to do this." Rather, respondents felt that research would be one way to "get policymakers to understand that [urban farms are] needed in the community and access to food should be a huge priority and that urban agriculture is one way of addressing some of these needs so that they put [enabling] policies in place." Further, it would be a way to reach a wide range of decision-makers with different political or organizational interests. For example, one municipal staff-person noted:

The Economic D evelopment Committee- I mean it's usually primarily made up of conservative councilors... if you position urban agriculture as the touchy, feely, really good type stuff... it's not going to play well to that kind of audience. They understood right because they understood the economics of it. So it's how do you position urban agriculture in a way that not just the conservationist councilors in the city, and there's lots of those, but that all the councilors can understand what kind of an effect this has. 
Translating Policies to Investments and Procedures Several key informants identified a need to inform their own investment and implementation decisions. As one respondent noted, "that's the kind of research that we would look at and say should we or shouldn't we get into food in a more intentional way?...So yes, absolutely I think it can help and also for us I think it helps validate why we've invested so much money in food from a social enterprise perspective you know." Another suggested research could be used to attract investment in local food entrepreneurs or could inform pilot projects: "I think we can [use the data to] do more together to actually create some implementation plans together as well and the pilots... if it's not successful, then you re-evaluate, you re-interpret and refresh."

Several key informants noted the need for detailed evidence to support the translation of polices (the broad rules and frameworks for urban agriculture) into prooedures (the mechanisms by which policies are enacted and implemented) to support investment and implementation of urban agriculture in Toronto. For example, one municipal worker noted that "we have committed to greatly increasing civic engagement [including urban agriculture].... Unfortunately they didn't pass the budget to make it so." Another saw health impact assessments (HIA) research as a way to gain support from executives: "we just don't have the time, there are so many competing files... I just wish that our senior management would see it as a real opportunity, because I think it really does enhance the city and the health of the city and the people."

Indeed, the space between policy and procedure was identified as a major challenge facing the development of UA in Toronto. Repeatedly, key informants identified enabling policies or executive leadership positions supportive of UA that were contradicted by procedural issues on the ground in urban agriculture policy and practice. For example, a number of respondents noted a difference in flexibility and openness on bylaw interpretation depending on rank in the public service hierarchy: "You know, we've had generally good relationships particularly with the senior levels but there's been some disagreements and certainly some challenges at the individual level." Regarding sale of the produce of urban agriculture in urban parks, another respondent noted:

For [a public service leader] it was all about scale and interpretation and compatible use. You know from both of our perspectives, until it's a commercial scale where the uses are incompatible, we can probably interpret things favourably. Now, it's a lot different to talk to [public service leaders] about that than somebody on the ground who's like trying to make decisions about what can and can't happen... for example like putting up a greenhouse.

A lack of procedural and bylaw clarity results in challenges for those involved in enabling new urban agriculture interventions. O ne key informant noted, "if there's no guidance to planners or bylaws to enforce whether the land can be used for [urban agriculture], I think that could be a huge challenge because it could be not allowed with the way that a lot of the current language is on land use bylaws." For community groups, clarity is needed to make decisions around urban agriculture practice more transparent: "It's either interpretation or implementation right so one group is told they need a permit, another group in a different ward is told you don't. So it's a lot of inconsistencies."

Similarly, policy-level perspectives identified great potential for urban agriculture as an interim use of urban space: "O ur public space is going to be changing, it's so malleable, it's going to shift over time and this is part of that.... We should just embrace those shifts and those changing interests of our citizens in shaping and reshaping our city." However, those involved with direct implementation were much more cautious about interim use: "The interim use tends to lead to entitlement... put a community garden there or something else there as part of the things for the next two or three years and then, you know, when you try to remove it or stop the use, then the [stuff] hits the fan."

Urban agriculture as a shared use of public space, particularly in parks, raised similar concerns:

People perceiving that a group has hijacked public space, that they're using it you know, 
there may be an inactive sports activity or some other community group that was displaced in order to achieve that, there might be use conflicts with animals and dogs and off-leash areas.

For those working on the front lines, clear policies and procedures are important for everyday community engagement in spaces of urban agriculture:

The policy becomes very important in having a strong footing for our folks on the street who have to defend to the yelling citizen who is telling them they're useless pieces of garbage and overpaid... It's very important to have a strong footing for our frontline staff to feel comfortable in those engagements.

Potential Indicators and M etrics We grouped potential indicators into five broad categories (see Table 1).

\section{Economic development and employment:}

There was an emphatic agreement among respondents from all sectors that economic indicators were of primary importance in making the case for urban

Table 1. Categories and Areas of Interest to Municipal Staff and Policy-Makers in Relation to Urban Agriculture and Health, Ranked by Salience

\begin{tabular}{|c|c|}
\hline Broad Category & Main areas of interest for indicators-metrics \\
\hline $\begin{array}{l}\text { 1. Economic development } \\
\text { and employment }\end{array}$ & $\begin{array}{l}\text { - Financial benefits to local organizations } \\
\text { - Employment } \\
\text { - Quality of jobs } \\
\text { - Job preparedness training opportunities } \\
\text { - Farmer viability }\end{array}$ \\
\hline 2. Equity \& health & $\begin{array}{l}\text { - Access to healthy fruits and vegetables } \\
\text { - Food bank use } \\
\text { - Physical activity levels } \\
\text { - Healthy eating habits } \\
\text { - Nutrition-related health outcomes (such as diabetes) } \\
\text { - General food and environmental literacy } \\
\text { - Mental health } \\
\text { - Providing community to new immigrants }\end{array}$ \\
\hline 3. Risk & $\begin{array}{l}\text { - } \text { Costs } \\
\text { - Food safety } \\
\text { - Personal injury } \\
\text { - Litigation } \\
\text { - Environmental health risks (e.g., soil toxicity, dog urine) } \\
\text { - Garden waste and compost } \\
\text { - Aesthetics }\end{array}$ \\
\hline 4. Land use and production & $\begin{array}{l}\text { - Number, size, and type of garden } \\
\text { - Types and amounts of food grown per acre } \\
\text { - Dollar sales per acre } \\
\text { - Import replacement levels } \\
\text { - Pollinator habitat }\end{array}$ \\
\hline 5. Partnerships and policies & $\begin{array}{l}\text { - Public awareness indicators such as the number of people touring urban agriculture } \\
\text { sites } \\
\text { - Support indicators including the number of new institutional supports or policies } \\
\text { instituted for urban agriculture } \\
\text { - Number of nature of inter-divisional, inter-governmental, and/ or cross-sectoral } \\
\text { collaborations } \\
\text { - Cross-sectoral effects on poverty and health care costs }\end{array}$ \\
\hline
\end{tabular}


agriculture to government decision makers, funders, entrepreneurs, and private sector actors. Traditional indicators of local economic development were of strong interest: financial benefits accruing to local organizations, numbers of new enterprises started, number of people employed in new enterprises, quality of new jobs produced (income security and wages), job preparedness and training data, and returns on investment (including case-bycase benefits for land developers [Section 37 benefits]; see City of Toronto, 2014). More specifically oriented to UA were economic sustainability and viability for farmers, multiplier effects for local vs. nonlocal foods, and economic opportunities in UA for equity-seeking communities. Unfortunately, these latter are not simple indicators but require substantially more analytical work than most municipal staff are given the time or resources to carry out.

Many key informants noted the importance of urban agriculture as a new job creator and space for entrepreneurship: "For me the purpose of engaging kids in our industry is [that it is] going to require a workforce ten or 15 years down the road... When the food industry is requiring people for it, there will be people... to fill the jobs." Others identified urban agriculture as a potential catalyst for local economic development, particularly in underserved communities, noting that urban agriculture could generate employment and play a "catalyst role in terms of kick starting development and the neighborhood regeneration that comes from that environment." As one respondent noted, "I think our crystallization point or coalescing point is food but we think food is a way to have a broader conversation about community development and strong resilient local economies."

Equity and health: The majority of key informants expressed strong interest in indicators of equity and health impacts across different population and demographic characteristics, such as age, ethnicity, immigration status, suburban or urban residence, and gender. This included impacts of UA on food security (such as affordability and food bank use). Food literacy and environmental literacy were the most frequently raised areas for indicator development around education and awareness relevant for health. The development of individual and community leadership and selfesteem were seen as important, but not fully framed as UA-specific indicators. Respondents were also interested in indicators of on-site health and safety related to personal and workplace injury and transportation risks.

The primary direct health indicator of interest was access to healthy fresh fruits and vegetables, particularly for equity-seeking communities in Toronto: "The benefit is really being able to grow food for people- right, fresh, affordable food right within the community." Access was defined in terms of price, availability, and quality (including nutrient information). Direct health benefits related to physical activity and healthy eating were also of interest, including traditional nutrition-related health outcomes such as decreased rates of diabetes. Environmental and ecological health indicators (e.g., air and soil impacts) were of interest to a minority of respondents.

Respondents explicitly linked access to healthy foods with urban health equity, and many identified nutrition, food security, and food literacy as key indicators of interest. A strong majority of respondents indicated interest in indicators of mental health benefits, particularly at the community level. This was described variously as social capital, sense of belonging, community and social health, engagement, and community pride. Measures of community interest in participation, opportunities to participate, and rates of participation in urban agriculture across the life course from childhood to old age were of interest. For example, a representative of a city-building organization noted urban agriculture's role in slowing the decline in social capital that takes place when new immigrants face barriers in realizing their Canadian dreams:

We're starting to look at this social capital piece from a whole slew of angles and urban agriculture is one of the angles because it's such a great place-based, space-based activity... a tool to bring people together. And divergent and diverse people together who may not agree on very much at all except that their hands are getting dirty and 
growing food is a common denominator and then eating that food is a common denominator.

D ata about impacts on social equity were perceived to be uniquely necessary in Toronto, where at the municipal level social equity is a major priority, and where the social mix differs from the more-often-studied American cities. The majority of respondents indicated a need for their own work to demonstrate a positive equity impact. Several noted ongoing challenges in the differential use of urban agriculture interventions by different communities- e.g., for newcomers and long-term residents. While most respondents raised challenges in grappling with these broader "soft" impacts, they also asserted that it was important to make the effort to measure them or conduct appropriate analyses to generate them. For example, one respondent suggested:

I would love to see how to measure the social capital. And it could be an index... it could be something along the lines of, you know, did you get to know people you wouldn't have known before? Did you work with people of other cultures from you? Did you work with people other ages from you? Did you get to know your neighbor and then see them again five months later or have another interaction with them in the winter after you did your planting in the spring, did you see them at the harvest and did you feel you made friends... because there's this idea around urban agriculture as being something that can actually spark a whole bunch of other things.

Risks: Several key informants, particularly municipal staff, identified ongoing risk aversion as a continued barrier. Respondents expressed concerns about environmental health, from pesticide education to dog urine to soil quality:

Soil toxics certainly [are] an issue that comes up over and over and over again. There is some discomfort from landowners including the City of Toronto in terms... whether or not somebody would come back and sue the city for allowing them to garden on contaminated lands... Of course all the produce you buy from Mexico and South America has no requirements for soil testing or, you know, so it's ironic that there's that level of discomfort.

Another risk identified by several key informants was the risk that local communities would not support unsightly or untidy urban gardens:

They have to understand that it's not a tidy business, so you can't necessarily have straight rows of pristine, weed free vegetables growing in an area... It's not a perfectly manicured flowerbed and that's what some of the people in urban agriculture are going to expect.

A related concern was in respect to waste management: "What do you do with all the waste, the garden waste or the compost at the end?... It will take some management, it will take some money and it won't be tidy." Perceived risks that key informants saw as particularly important to address included health and safety risks related to food safety and personal injury, alongside the potential for litigation: "Any of the risks that would be associated with physical activity would be also present with urban agriculture, urban gardening, you know, soil safety, walking safety, biking safety, all those sorts of things that we would want to ensure that we're creating spaces that minimize any of those risks." However, most noted that these barriers are part of the general and manageable cost of working in public parks and on public properties. Respondents were also interested in addressing community concerns over wildlife management: "For some people urban agriculture attracts rats or other scary things... there's a whole series of connotations associated with urban wildlife."

Several key informants saw an opportunity for information to be used to allay concerns of residents, funders, and political decision-makers. For example, one respondent suggested that "if it provides a positive supporting role to offset the concern of the councilor or the staff or senior 
management team or whatever, then that's how you should do it." Another suggested that "it's important that there just be... a number of supports for why it's a beneficial use as opposed to how or why it's a scary or frightening use." For municipal stakeholders, having city-generated data was also seen as helpful in addressing perceived risks:

It is helpful to us that the city has done its own research. We're not just saying oh yeah, this is a good idea. We're just saying based on this research, that the city undertook, this is what we know. You're much stronger, when you're putting forward a change or proposed best practice even, to have a substantive document or two.

The risk of failure of urban agriculture interventions was of interest to a majority of respondents. Key informants felt this risk took two forms: a lack of commitment and a lack of community proponents responsible for urban agriculture interventions wisely using resources. O ne respondent noted, "we had a farmer who left, so there's the risk of being associated with that lack of commitment or follow-through or skill set or tactical or financial capacity to implement or to make a success of the project." Another reported, "there's the risk of the property not being used for the purposes that you would like it to be used... We really try to promote agriculture that is organically produced so there's the risk that someone may not be producing according to [that standard]." These risks were particularly acute for landowners and investors. Funders noted the risk that capital improvements to make land useable for urban agriculture (on-site water, waste management, and so on) will be "potentially a waste of money or not being properly utilized." For some, the risk of failure is contextualized by a need for immediate evidence of success for urban agriculture pilots: "They had to say no, not because they're not interested. Because they just don't have the capacity right now, their model is to succeed. They have to build on that success over time so right now there's nobody actually that supports that."

However, for a notable subsection of munici- pal policy staff respondents, these risks were felt to be overblown: "These things will kind of have a life of their own. That there will be communities that will take it on and really make it successful and others that will not be as successful and yet the success might be on things that you cannot see or measure." Another suggested, "Things go wrong in these projects... we shouldn't run away and be scared from any kind of conflict or potential risks... .Like there's a risk that in five years nobody in that community will want a garden. Is that really a big risk? ... It's such a small risk. This is going to happen. It doesn't mean it's a failure." As another respondent advised:

Be bold. D on't let risk aversion prohibit your capacity to support the urban agriculture agenda... .Y ou know, for a long time it's been a lot of "we don't have the capacity, we don't have the resources, the staff, the financial investment, all of those things," so I think, you know, my advice would be just jump in.

Land use and production: Respondents felt that there is a lack of data about current agricultural land use against which to assess and understand changes and trends. The need for such data was best expressed at the city level: "The question is, how are we going to replace the farmland that we keep losing to developers?” D ata specific to UA included the number, size, and availability of appropriate locations; the number and size of current and new urban agriculture spaces by type (e.g., garden, farm, etc.); the amount of arable land; the farmland and greenspace preserved; and the benefits of using public space for urban agriculture. Similarly, levels of local production and consumption are not currently well understood. Respondents were interested in simple indicators such as: tons of food produced per acre, dollar sales per acre, and the UA amounts in farmers market sales. More analytically challenging were the import replacement levels and proportion of total consumption produced locally, the efficiency of land use per participant, and the energy use per urban agriculture intervention. Respondents were interested in the effect of urban agriculture sites on 
neighboring property values and in quantifying the environmental benefits of urban agriculture: "It provides for a number of benefits related to green space, water management, carbon securement, just in terms of providing open space for people to access... and abundant environment for wildlife and pollinators." Most respondents conceptualized these benefits in terms of urban environmental transformations that have both ecological benefits, e.g., "turning some concrete and non-permeable places into permeable places, so that we can recharge groundwaters and avoid flooding," - and social ones:

It just makes a city better. I think that this is what an urban farm can do. It can be a part of that feeling in a neighborhood where it's like there are cool things happening in my neighborhood, I live in a cool neighborhood. Like everybody has that feeling right that there's something special in my neighborhood and I appreciate that.

For several respondents, urban agriculture represented a productive use of otherwise "unproductive" urban spaces: "Making use of land that's currently vacant or not being used and using it for something like growing food is a really positive thing rather than it being, you know, filled with weeds or whatever is happening to it now." This transformation was seen as an opportunity for communities and cities to resist development pressures and to reclaim green spaces for their own use. O ne respondent addressed the effect at the community level:

First off, it's a land that's being put to use. It's not being contaminated.... So it's an opportunity to see your community in a different light. Most of our communities are filled with high rise buildings and townhouses, so to see a well maintained green space, like down at the creek... we have the creek down there that families can actually take walks in.

Partnerships and policies: Key informants indicated interest in indicators related to the ongoing development of partnerships and policies for urban agriculture, given the need for cross department, division, and sector linkages. For example, there was strong interest in tracking changes in government spending on parks (e.g., more community gardens, less other garden maintenance) and spending on urban agriculture spaces per capita, (e.g., for community-based programs on the municipal side or developer investments in growing spaces on roofs or on land surrounding developments). D espite the analytical challenges they pose, key informants were also interested in the potential impacts on poverty levels and even healthcare costs near urban agriculture interventions. Broader partnership indicators of interest included the number and type of different governance models for urban agriculture projects, indicators of cross-divisional and intergovernmental cooperation and partnership, awareness indicators such as the number of people touring urban agriculture sites, and support indicators such as the number of new partnerships, policies, and institutional supporters for urban agriculture. Many respondents noted a need to document and understand collaborations in order to facilitate new investments within and across different levels of government. As one noted,

We're always talking about breaking down silos between ministries. Even within municipalities, you know, the health people work in their part of the world and the planners work in their part of the world.... There is a strength when you do that collaboration and work across the sectors. We haven't even begun to do what we could do there yet.

Some respondents saw research as a way to provide guidance by sharing best practices: "what is working, what are the challenges and, you know, sort of case study type of information so that others can learn." Several respondents pointed to the need to look beyond Toronto's borders for health evidence and best practices: "if you reach out to the partners, then you can say to them we would really benefit from your research, from your models, from your knowledge and then you build that capacity."

Key informants took seriously their potential 
to widely influence future policy and programs: "O ur public space is going to be changing. It's so malleable. It's going to shift over time and this is part of that... We should just embrace those shifts and those changing interests of our citizens in shaping and reshaping our city."

Key Informant Perspectives on Knowledge E x change Many key informants had advice regarding the design and communications style of research reports. Most suggested a succinct, readable format accessible to a wide range of audiences with little time to read long research reports:

I think being able to make the information and the research you find accessible but also just easy to digest... the purpose of the research is to actually change behavioural impacts systemically and we've got to do that in a way that's easily, can be easily consumed by those people who actually get it.

The majority of key informants suggested a combination of pictures, stories, case examples, and infographics to support and complement the numerical data. $O$ ne respondent suggested that photos are particularly important in the case of urban agriculture, which is "really a hidden and invisible activity in our city... it's like people just have no idea [it is happening]." O thers suggested that the inclusion of case studies and examples is essential: "The combination of some really good research and indicators coupled with some great projects is like the wow factor... So if we can have the numbers and the stories, I think it will be quite powerful actually." At the same time, key informants remained focused on obtaining strong evidence: "It's not just anecdotal, there is actual hard evidence and there's appropriate research methodologies"; "We're much more successful here with policy... now that we've taken on more evidence based approach."

Many key informants identified a need to specifically identify and target key audiences for research results: "Y ou've got to figure out how to package it and spin it in a way that it's going to get the attention of whoever you're looking to get the attention of." For some respondents, that target was industry and required a strong economic evidence base; for others, the target was city council and a strong message related to health and social equity; for still others, it was equity-seeking residential communities seeking evidence that informs and supports action:

The community has been researched over and over and over again so if families are to see a report back of a research that was done and they're able to see some action items come out of that research, some follow up and a follow through, I think that serves a community better than a report and you don't hear from the people again.

\section{Discussion}

O ur findings indicate a nuanced understanding of the complexities of urban food systems governance and UA policy-making and implementation among our respondents, perhaps due to the extensive advocacy work done by members of G rowTO (UA entrepreneurs and community members) working with enlightened Toronto Agriculture Programme staff over time (Sommerfreund, Cook, \& Emmanuel, 2016). On the other hand, our research confirmed the need for substantially more research around a wide range of potential quantifiable indicators relevant to urban agriculture and health in the City of Toronto. These would include a mix of simpler measures and more analytically demanding derived indicators, in which attribution to UA activities would be more explicit. Place-specific equity and economic data were of particular Salience among our key informants. Such data were collected, as part of the increasingly pressing priority to support the development of a just, growing, and viable urban food system (Raja et al., 2017). The key role of economic development and employment influenced revisions to the Toronto Food Strategy as can be seen in Figure 1. While improving the food environment, healthy food access, and food literacy are all present, community-building and inclusion, community economic development and infrastructure, and supply-chain improvements represent half of the food system themes.

Some of our interviewees expressed skepticism 


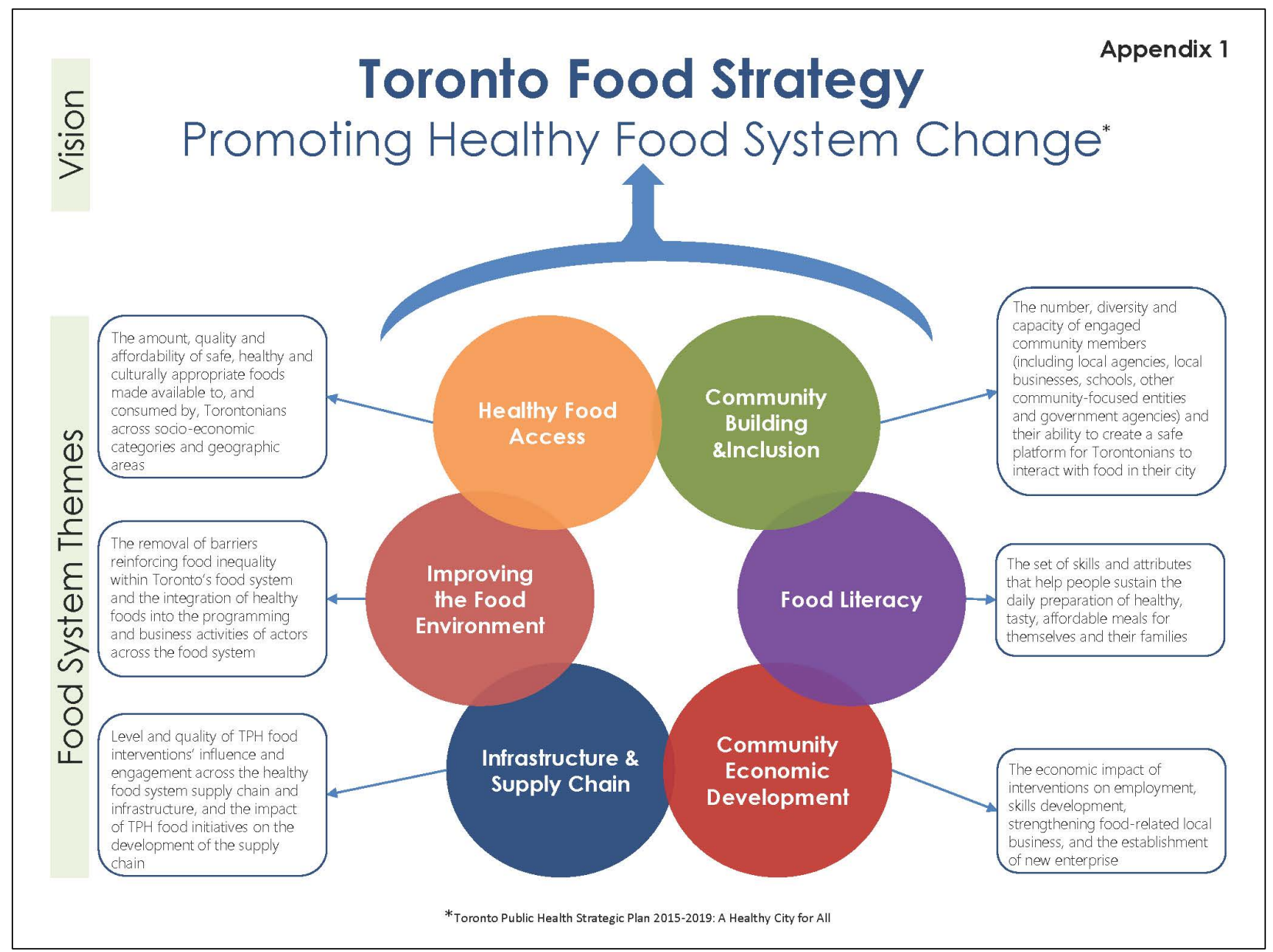

Source: Toronto Public Health Strategic Plan 2015-2019: A Healthy City for All (http:// www.toronto.ca/ legdocs/ mmis/2015/ hl/ bgrd/ backgroundfile-80217.pdf)

about the benefits of UA and the extent and breadth of potential impacts. Existing evidence indicates that urban gardens function at very different levels of productivity depending on inputs, skill, time available, and likely soil quality and unmeasured factors (CoD yre, Fraser, \& Landman, 2015; Smith \& Harrington, 2014). In the experience of our grower colleagues from diverse communities, much depends on the quality of land provided, prior experience with growing (which is more common in elders), inputs, support for communities of colour, and the extent of training provided to younger growers through mentorship by elders in programs run by community organizations (AfriCan Food Basket, n.d.). Systematic sampling and estimation of food production values in Madison, Wisconsin, were substantial - over US\$7 million (Smith \& Harrington, 2014), although only a few households were likely producing more than they needed and hence contributing to markets as well as household livelihoods. Hunold and colleagues found that about half of Philadelphia urban and peri-urban farms (10/20) were profitable until labor costs were included in calculations, when it dropped to $3 / 20$ (Hunold, Sorunmu, Lindy, Spatari, \& Gurian, 2017, p. 62, Table 2).

Hence, additional data collection is needed on the skill development, job creation, and other community economic development impacts of urban agriculture programs in order to respond to the information needs of municipal policy-makers. Informed by our work, the Toronto Urban G row- 
ers (Teitel-Payne et al., 2016) program was funded by Toronto Public Health to consult stakeholders within the urban growing community on which production relevant indicators are most relevant to them and which would be feasible to collect. Considerable overlap can be seen in the categories and areas of interest, though more specificity is apparent, relevant to their role as producers (see Figure 2).

Subsequent work on indicators has been extended to the city-region food system (Miller, 2016), with noted persistent gaps in information on urban agriculture production, as one of the alternatives to the dominant food system.

Hesitations about risks were prominent among categories of indicators. Managing potential risks to health has been a key role for public health in many urban agriculture programs, particularly around metal contamination of soil (Witzling, Wander, \& Phillips, 2011). In a parallel process, Toronto Public Health staff (led by author Archbold), informed by this study, revisited the soil guidelines (TPH, 2011 amended 2017). Cowling and colleagues (2017), in their review of health impact assessments (HIA) centered around agriculture, note that environmental hazards were one of the health impacts examined in the HIA done for the Urban Agriculture Overlay District in Cleveland, O hio, (2012) along with empowerment and food access. Similar HIA processes can be applied more explicitly to scope, likely hazards, and benefits through HIA (Mittelmark, 2001) by selecting among the categories and areas of interest laid out in Table 1. Such HIAs may be more feasible than widespread primary data collection for informing policymakers (D annenberg et al., 2006). Combined with data from interviews, such as from this study, HIAs can hone in on areas of greater uncertainty and higher importance, guiding additional data collection and analysis (McCallum, Ollson, \& Stefanovic, 2015). Municipal policy-makers should be allocating resources to generate such data and analyses to assuage both public concerns as well as their own.

\section{Conclusions}

This research validates calls for multifunctional approaches to understanding and developing more equitable urban food systems (Morgan, 2015; Tornaghi, 2014; Raja et al., 2017; Sonnino, 2013) at the intersections of population health, environmental sustainability, and urban governance. In this study, municipal staff and policy-makers wanted local, tangible evidence that urban agriculture could help them achieve their social, economic, and environmental goals in a way that brought about meaningful impacts for local communities, with any risk being worth the reward. They were willing to work with researchers to conduct deeper investigations of urban agriculture's potential health equity dimensions in a complex and evolving multicultural context such as Toronto's. These might include mixed methods examinations of the policy-procedure dynamic for UA interventions in different settings, from park-based produce sales, to interim uses of fallow spaces, to shared land uses in civic spaces. Priorizing resources to conduct more thorough investigations or assessments of the risks- both real and perceived - and ways to mitigate them would also be important in order to move from high-level endorsements to on-theground interventions in urban agriculture.

At the same time, staff and policy-makers in multiple local government sectors can reach out to health departments to provide evidence, to champion inclusive UA approaches, and to provide funding for key community stakeholders. Brainstorming together may help tackle thomy conflicts, such as dog parks versus community gardens, into better operationalize UA.

Health departments can build on equity oriented healthy public policy approaches to join with their Economic Development, Community Services, and Parks department colleagues. This would allow them to not only work together, but also to support community organizations, which often have a greater scope for action than municipal staff. Cross-departmental or cross-divisional work that includes community organizations can also involve the full range of municipal councilors and representatives to generate the broad support required to approve and fund UA initiatives. O ur research indicates that such activities may better realize the multitude of potential benefits that inclusive UA can generate as part of broader food system change. 
Figure 2. Production-Related Indicators for Urban Agriculture in Toronto; Toronto Urban Growers

\section{INDICATORS FOR URBAN AGRICULTURE (UA) IN TORONTO}

\section{f. Associated with positive physical and / or mental health benefits \\ Baseline Measures TYPE OF ORGANIZATION \\ \# of different types of organizations

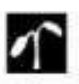 \\ TYPE OF URBAN AGRICULTURE PRACTICED \\ \# of different types of agriculture \\ N of types of facilities \\ N of types of land tenure

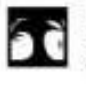 \\ DIVERSITY OF URBAN AGRICULTURE PRODUCTS \\ \# of products grown by UA projects \\ 6 \\ B. \\ PARTICIPATION RATE \\ N of people participating in UA \\ Amount of time spent in UA activities \\ $\%$ of people in types of UA programs \\ " of projects maintaining wait lists. \\ * of people waiting to access UA prograrns and plots \\ \# of people in different roles (staff, growers, volunteers)

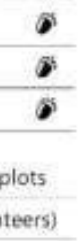

\section{Economic}

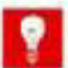

LOCAL ECONOMIC DEVELOPMENT

Total revenue generated from sales of food

N of growers supplementing their income with produce sales

\section{PATHWAYS TO EMPLOYMENT}

" of UA programs offering training in employment-related skills

\# of people the farm/garden has trained in employment related skills

\# of types of skills taught

\# of population subsets trained by UA organizations

\section{Social}

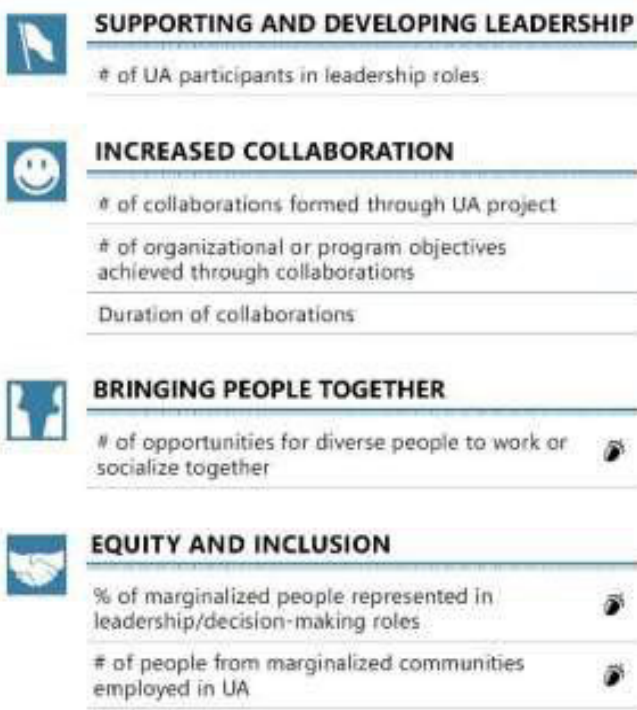

\section{Environmental}

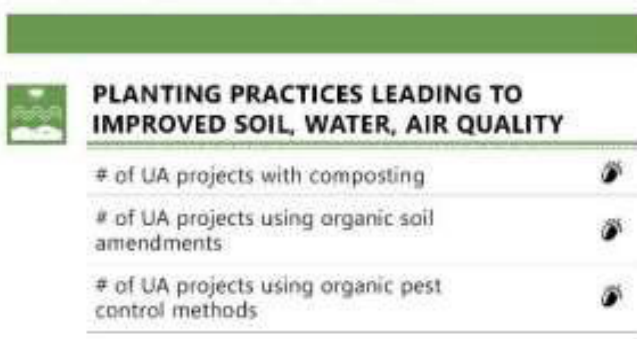

- STORM WATER MANAGEMENT AND WATER CONSERVATION

* of UA projects collecting rainwater

\# of UA projects using efficient watering practices

\section{INCREASED AND DIVERSIFIED URBAN} GREEN SPACE

* (sq footage) of unused/underused land placed into food production

INCREASED BIODIVERSITY

N of UA projects that grow native/pollinator plants

Source: Teitel-Payne, R., Kuhns, J., \& Nasr, J. (2016). Indicators for urban agriculture in Toronto: A scoping analysis. Toronto Urban Growers. Retrieved from http:/ / torontourbangrowers.org/ img/ upload/ Indicators_AODA.pdf 
Journal of Agriculture, Food Systems, and Community Development

ISSN: 2152-0801 online

https:/ / www.foodsystemsjournal.org

\section{Acknowledgments}

Ronald Macfarlane, Kate Bassil, Monica Campbell,

members of the Healthier Harvest Research

Loren Vanderlinden, Barbara Emanuel and the

\section{References}

AfriCan Food Basket. Cultivating Y outh Leadership: Urban Farm Project (CYL) (n.d.). Accessible at http:/ / africanfoodbasket.ca/ our-work/

Armstrong, D . (2000). A survey of community gardens in upstate New Y ork: Implications for health promotion and community development. H ealth \& Plaœ, 6, 319-327. https:/ / doi.org/ 10.1016/ S1353-8292(00)00013-7

Baker, L. (2002). Seeds of our aity. Toronto: FoodShare.

Baker, L. (2004). Tending cultural landscapes and food citizenship in Toronto's community gardens. G eographical Review, 94 (3), 305-325. https:/ / doi.org/ 10.1111/ j.1931-0846.2004.tb00175.x

Barwick, M. (2008, updated 2013). Knowledge T ranslation Planning T emplate. O ntario: The Hospital for Sick Children. Retrieved from http:/ / www.sickkids.ca/ pdfs/ Learning/ 58366-58366-KT Template.pdf

Beckie, M., \&. Bogdan B. E. (2010). Planting roots: Urban agriculture for senior immigrants. Journal of A griculture, Food Systems, and Community D evelopment, 1(2), 77-89. https:/ / doi.org/ 10.5304/ jafscd.2010.012.004

Brown, K., \&. Jameton, A. (2000). Public health implications of urban agriculture. Journal of Public H ealth Policy, 21(1), 2039. https:/ / doi.org/ 10.2307/ 3343472

Blay-Palmer, A. (2009). The Canadian Pioneer: The genesis of urban food policy in Toronto. Journal of International Planning Studies, 14(4), 401-416. https:/ / doi.org/ 10.1080/ 13563471003642837

Blay-Palmer, A., Renting, H., \& D ubbeling, M. (2015). City-region food systems: A literature review. Wilfred Laurier University Centre for Sustainable Food Systems \& RUAF Foundation. Retrieved from http:// www.ruaf.org/ sites/ default/ files/ City\%20Region\%20Food\%20Systems\%20literature\%20review.pdf

Boston, City of. (2017). Urban Farming in the City: Learn more about how the Office of Food Access supports farming in Boston. Retrieved from https:/ / www.boston.gov/ health-and-human-services/ urban-farming-city

Brand, C., Bricas, N., Conaré, D., D aviron, B., D ebru, J., Michel, L., \& Toussanit-Soulard, C. (coordinateurs). (2017). Construire des politiques alimentaires urbains. Conœpts et démarches [Building urban food policies: Concepts and approaches]. Versailles cedex, France: Editions Q uae.

Cabannes, Y., \& Raposo, I. (2013). Peri-urban agriculture, social inclusion of migrant populations and Right to the City. City, 17(2), 235-250. https:/ / doi.org/ 10.1080/ 13604813.2013.765652

City of Toronto. (2012). G rowT 0 : A n urban agriaulture action plan for Toronto. Retrieved from http:/ / www.toronto.ca/ legdocs/ mmis/ 2012/ pe/ bgrd/ backgroundfile-51558.pdf

City of Toronto. (2013). T oronto A gricultural Program. Retrieved from http:/ / www.toronto.ca/ legdocs/ mmis/ 2013/ pe/ bgrd/ backgroundfile-62375.pdf

City of Toronto. (2015). T 0 Prosperity: T oronto Poverty Reduction Strategy. Retrieved from https:// www.toronto.ca/ wpcontent/ uploads/2017/ 11/ 9787-TO Prosperity Final2015-reduced.pdf

City of Toronto \& G ladki Planning Associates (Prepared by). (2014). Section 37 Review Final Report. Retrieved from http:// www.toronto.ca/ legdocs/ mmis/ 2014/pg/ bgrd/ backgroundfile-66994.pdf

Clapp, J., D esmarais, A., \& Margulis, M. (2015). Mapping the state of play on the global food landscape. Canadian F ood Studies, 2(2), 1-6. https:/ / doi.org/ 10.15353/ cfs-rcea.v2i2.103

Clark, J. K., Freedgood, J., Irish, A., Hodgson, K., \& Raja, S. (2017). Fail to include, plan to exclude: Reflections on local governments' readiness for building equitable community food systems. Built E nvironment, 43(3), 315-327. https:// doi.org/ 10.2148/ benv.43.3.315

CoD yre, M., Fraser, E. D . G., \& Landman, K. (2015). How does your garden grow? An empirical evaluation of the costs and potential of urban gardening. U rban F orestry \& U rban G reening, 14(1), $72-79$. https:// doi.org/ 10.1016/ j.ufug.2014.11.001

Cohen, N., Reynolds, K., Sanghvi, R., \& Chou, J. (Eds.). (2012). Five Borough Farm: Seeding the F uture of U rban A griculture in N ew Y ork City. N Y C, N Y , U SA (1st ed.). New Y ork: D esign Trust for Public Space. Metrics framework accessible at http:// www.fiveboroughfarm.net/ pdf/ 5BF Metrics poster.pdf 
Colasanti, K. (2009). G rowing food in the city: Two approaches to ex ploring scaling up urban agriaulture in D etroit (Unpublished doctoral dissertation). Michigan State University, D etroit, Michigan.

Cole, D ., Grace, D ., \& Diamond, M. (2008). Researchers' approaches to evidence on urban agriculture and human health. In D. C. Cole, D. Lee-Smith, \& G . Nasinyama (Eds.), H ealthy city harvests: G enerating evidenœ to guide policy on urban gardening (pp. 31-47). Lima, Peru: CIP/ Urban Harvest and Makerere University Press.

Cowling, K., Lindberg, R., Dannenberg, A. L., Neff, R. A., \& Pollack, K. M. (2017). Review of health impact assessments informing agriculture, food, and nutrition policies, programs, and projects in the United States. Journal of A griculture, Food Systems, and Community D evelopment, 7(3), 139-157. https:/ / doi.org/ 10.5304/ jafscd.2017.073.009

Dannenberg, A. L., Bhatia, R., Cole, B. L., D ora, C., Fielding, J. E., Kraft, K.... Tilson, H. H. (2006). Growing the field of health impact assessments in the United States: An agenda for research and practice. A merican Journal of Public H ealth, 96 (2), 262-270. https:/ / doi.org/ 10.2105/ AJPH.2005.069880

Draper, C. \&. Freedman. D . (2010) Review and analysis of the benefits, purposes, and motivations associated with community gardening in the United States. Journal of Community Practio, 18(4), 458- 492. https:/ / doi.org/ 10.1080/ 10705422.2010.519682

Forster, T., Egal, F., Renting, H., D ubbeling, M., \& Escudero, A. G . (Eds.). (2015). Milan U rban F ood Policy Pact. Selected good practios from aities. Milan, Italy: Fondazione Giangiacomo Feltrinelli . Retrieved from http:// www.ruaf.org/publications/ good-urban-food-policy-practices-cities

Gore, C. (2008). Healthy urban food production and local government. In D . C. Cole, D. Lee-Smith, \& G. Nasinyama (Eds.), $\mathrm{H}$ ealthy city harvests: $\mathrm{G}$ enerating evidence to guide policy on urban agriculture (pp. 49-65). Lima, Peru: International Potato Center and Makerere University Press.

Guitart, D., Pickering, C., \& Byrne, J. (2012). Past results and future directions in urban community gardens research. U rban F orestry \& U rban G reening, 11(4), 364-373. https:/ / doi.org/ 10.1016/ j.ufug.2012.06.007

Hunold, C., Sorunmu, Y., Lindy, R., Spatari, S., \& G urian, P. L. (2017). Is urban agriculture financially sustainable? An exploratory study of small-scale market farming in Philadelphia, Pennsylvania. Journal of A griaulture, F ood Systems, and Community D evelopment, 7(2), 51-67. https:// doi.org/ 10.5304/jafscd.2017.072.012

Heynen, N., Kaika, M., Swyngedouw, E. (Eds). (2005). In the nature of cities: U rban political ecology and the politics of urban metabolism. New York: Routledge.

Holland, L. (2004). Diversity and connections in community gardens: A contribution to local sustainability. L ocal E nvironment: The International Journal of Justice and Sustainability, 9(3), 285-306. https:// doi.org/ 10.1080/ 1354983042000219388

Ikerd, J. (2017). The economic pamphleteer: The urban agriculture revival. Journal of A griaulture, F ood Systems, and Community D evelopment, 7(3), 13-16. https:// doi.org/ 10.5304/ jafscd.2017.073.007

International Panel of Experts on Sustainable Food Systems [IPE S-Food]. (2017). U nravelling the food-health nex us: A ddressing practioes, political economy, and power relations to build healthier food systems. Global Alliance for the Future of Food and IPES-Food. Retrieved from http:/ / www.ipes-food.org/ images/ Reports/ Health_FullReport.pdf

Keil, R. (2003). Urban political ecology1. U rban G eography, 24 (8), 723- 738. https:/ / doi.org/ 10.2747/ 0272-3638.24.8.723

Keil, R. (2005). Progress report- Urban political ecology. U rban G eography, 26(7), 640-651. https:// doi.org/ 10.2747/ 0272-3638.26.7.640

Kingsley, J. "Y.," \& Townsend, M. (2006). 'Dig in' to social capital: Community gardens as mechanisms for growing urban social connectedness. U rban Policy and Research, 24(4), 525-537. https:// doi.org/ 10.1080/ 08111140601035200

Kortright, R., \& Wakefield, S. (2011). Edible backyards: A qualitative study of household food growing and its contributions to food security. A griculture and H uman V alues, 28(1), 39-53. https:/ / doi.org/ 10.1007/ S10460-009$\underline{9254-1}$

Krippendorff, K. (2013). Content analysis: A n introduction to its methodology (3rd ed.). Thousand Oaks, CA: SAGE.

MacRae, R., G allant, E., Patel, S., Michalak, M., Bunch, M., \& Schaffner, S. (2010). Could Toronto provide 10\% of its fresh vegetable requirements from within its own boundaries? Matching consumption requirements with growing spaces. Journal of A griculture, F ood Systems, and Community D evelopment, 1(2), 105-127. http:// doi.org/ 10.5304/ jafscd.2010.012.008 
Journal of Agriculture, Food Systems, and Community Development

ISSN: 2152-0801 online

https:/ / www.foodsystemsjournal.org

Masson-Minock, M., \& Stockmann, D. (2010). Creating a legal framework for urban agriculture: Lessons from Flint, Michigan. Journal of A griaulture, F ood Systems, and Community D evelopment, 1(2), 91-104. https:// doi.org/ 10.5304/ jafscd.2010.012.007

McCallum, L. C., Ollson, C., \& Stefanovic, I. (2015). Advancing the practice of health impact assessment in Canada: O bstacles and opportunities. E nvironmental Impact A ssessment Review, 55, 98-109. https:/ / doi.org/ 10.1016/ j.eiar.2015.07.007

McClintock, N., Wooten, H., \& Brown, A. H. (2012). Toward a food policy "first step" in O akland, California: A food policy council's efforts to promote urban agriculture zoning. Journal of A griculture, Food Systems, and C ommunity D evelopment, 2(4), 15-42. https:/ / doi.org/ 10.5304/ jafscd.2012.024.009

McClintock, N. (2014). Radical, reformist, and garden-variety neoliberal: Coming to terms with urban agriculture's contradictions. L ocal E nvironment, 19(2), 147-171. https:/ / doi.org/ 10.1080/ 13549839.2012.752797

McCormack, L. A., Laska, M. N., Larson, N., \& Story, M. (2010). Review of the nutritional implications of farmers' markets and community gardens: A call for evaluation and research efforts. Journal of the A merican D ietetic A ssociation, 110(3), 399-408. https:/ / doi.org/ 10.1016/ j.jada.2009.11.023

Meenar, M. R. (2017). Assessing the spatial connection between urban agriculture and equity. Built E nvironment, 43(3), 364-375. https:/ / doi.org/ 10.2148/ benv.43.3.364

Meenar, M. R., \& Hoover, B. M. (2012). Community food security via urban agriculture: Understanding people, place, economy, and accessibility from a food justice perspective. Journal of A griaulture, Food Systems, and C ommunity D evelopment, 3(1), 143-160. https:/ / doi.org/ 10.5304/ jafscd.2012.031.013

Miller, S. (2016). City Region F ood System A ssessment T oronto (unpublished report). Interim Report \#2: Critical issues and key indicators.

Mittlemark, M. (2001). Promoting social responsibility for health: Health impact assessment and healthy public policy at the community level. H ealth Promotion International, 16 (3), 269-274. https:/ / doi.org/ 10.1093/ heapro/ 16.3.269

Morgan, K. (2015). Nourishing the city: The rise of the urban food question in the Global North. U rban Studies, 52(8), 1379-1394. https:// doi.org/ 10.1177/ 0042098014534902

Nasr, J., MacRae, R., \& Kuhns, J. (2010). Scaling up urban agriculture in T oronto: Building the infrastructure. Toronto: Metcalf Foundation. Retrieved from http:/ / metcalffoundation.com/ wp-content/ uploads/ 2011/ 05/ scaling-urbanagriculture.pdf

National Collaborating Centre for D eterminants of Health [NCCD H]. (2013). L et's talk: U niversal and targeted approaches to health equity. Antigonish, NS: National Collaborating Centre for D eterminants of Health, St. Francis Xavier University. Retrieved from http:/ / nccdh.ca/ images/ uploads/Approaches_EN_Final.pdf

Ontario, G overnment of. (2013). Local Food Act, 2013, S.0 . 2013, c. 7. Retrieved from http:/ / www.elaws.gov.on.ca/ html/ statutes/ english/ elaws statutes 13107 e.htm

Pearson, L. J., Pearson, L., \& Pearson, C. J. (2010). Sustainable urban agriculture: Stocktake and opportunities. International Journal of A gricultural Sustainability, 8(1-2), 7-19. https:/ / doi.org/ 10.3763/ ijas.2009.0468

Prain, G ., Lee-Smith, D., \& Cole, D . C. (2008). Urban governance for healthy and sustainable cities: The role of agriculture. In D. C. Cole, D. Lee-Smith, \& G. Nasinyama (Eds.), H ealthy city harvests: $G$ enerating evidence to guide policy on urban agriculture (pp. 231-244). Lima, Peru: International Potato Center and Makerere University Press.

Raja, S., Morgan, K., \& Hall, E. (2017). Planning for equitable urban and regional food systems. Built E nvironment, 43(3), 309-314. https:/ / doi.org/ 10.2148/ benv.43.3.309

Reynolds, K., \& Cohen, N. (2016). Beyond the kale: U rban agriaulture and social justice activism in N ew Y ork City. Athens: University of G eorgia Press.

Saul, N., \& Curtis, A. (2013). The Stop: H ow the fight for good food transformed a community and inspired a movement. Brooklyn, NY: Melville House.

Smith, V. M., \& Harrington, J. A. (2014). Community food production as food security: Resource and market valuation in Madison, Wisconsin (USA). Journal of A griculture, F ood Systems, and Community D evelopment, 4(2), 61-80. https:/ / doi.org/ 10.5304/ jafscd.2014.042.006 
Sommerfreund, J., Cook, B., \& Emanuel, B. (2015). Toronto Agriculture Program [Chapter in T oronto F ood Strategy: 2015 U pdate (pp. 19-22)]. Retrieved from http:/ / www.toronto.ca/ legdocs/ mmis/ 2015/ hl/ bgrd/ backgroundfile80219.pdf

Sonnino, R. (2009). Feeding the city: Towards a new research and planning agenda. International Planning Studies, 14(4), 425-435. https:// doi.org/ 10.1080/ 13563471003642795

Sonnino, R. (2013). Local foodscapes: Place and power in the agri-food system. A cta A griculturae Scandinavica, Section BSoil \& Plant Science, 63(Suppl. 1), 2- 7. https:/ / doi.org/ 10.1080/ 09064710.2013.800130

Teitel-Payne, R., Kuhns, J., \& Nasr, J. (2016). Indicators for urban agriculture in T oronto: A soping analysis. Toronto Urban G rowers. Retrieved from http:// torontourbangrowers.org/ img/ upload/Indicators_AOD A.pdf

Tomaghi, C. (2014). Critical geography of urban agriculture. Progress in H uman G eography, 38(4), 551-567. https:// doi.org/ 10.1177/ 0309132513512542

Toronto Food Policy Council. (2010). Toronto Food Strategy. Available in the Toronto Food Policy Archive http:/ / tfpc.to/ wordpress/ wp-content/ uploads/ 2015/ 05/ Toronto-Food-Policy-Archive-Spring-2015.pdf

Toronto Public Health [TPH]. (n.d.). T oronto Public H ealth Program Map. https:/ / www.toronto.ca/ wpcontent/ uploads/ 2017/ 11/ 91b9-Program-Map-TPH.pdf

TPH. (2011). A ssessing urban impacted soil for urban gardening: D ecision support tool - T echnical report and rationale. Toronto: City of Toronto.

TPH. (2013). From the ground up: G uide for soil testing in urban gardens. Retrieved from http:// hogn.ca/ wpcontent/ uploads/ 2015/ 04/ Guide-for-Soil-Testing-in-Urban-Gardens.pdf

Toronto Region Conservation Authority. (2013). U rban agrialture. Retrieved from https:/ / trca.ca/ conservation/ urban-agriculture/

Vidgen, H. A., \&. G allegos, D. (2011). W hat is food literacy and does it influenœ what we eat: A study of A ustralian food ex perts, Brisbane: Q ueensland University of Technology. Retrieved from https:/ / eprints.qut.edu.au/ 45902/

Vineland Research and Innovation Centre, Toronto Food Policy Council, \& Toronto Public Health. (2013). Feeding diversity: $\mathrm{C}$ ommunity acess and commercialization of world crops. Retrieved from https:/ / foodsecurecanada.org/ sites/ foodsecurecanada.org/ files/ feedingdiversityassessmentreport jan13.pdf

Wakefield, S., Y eudall, F., Taron, C., Reynolds, J., \& Skinner, A. (2007). Growing urban health: Community gardening in South-East Toronto. H ealth Promotion International, 22(2), 92-101. https:/ / doi.org/ 10.1093/ heapro/ dam001

Warren, E., Hawkesworth. S., \& Knai, C. (2015). Investigating the association between urban agriculture and food security, dietary diversity, and nutritional status: A systematic literature review. Food Policy, 53, 54-66. https:// doi.org/ 10.1016/j.foodpol.2015.03.004

Wegener, J., Hanning, R. M., \& Raine, K. D. (2012a). Generating change: Multisectoral perspectives of key facilitators and barriers to food system making. Journal of $\mathrm{H}$ unger and $\mathrm{E}$ nvironmental $\mathrm{N}$ utrition, 7(2-3), 137-148. https:/ / doi.org/ 10.1080/ 19320248.2012.707115

Wegener, J., Hanning, R. M., \& Raine, K. D . (2012b). Insights into the government's role in food system policy making: Improving access to healthy, local food alongside other priorities. Journal of E nvironmental Research and Public $\mathrm{H}$ ealth, 9(11), 4103-4121. https:/ / doi.org/ 10.3390/ ijerph9114103

White, M. M. (2011). D-Town Farm: African American resistance to food insecurity and the transformation of D etroit. E nvironmental Practice, 13(4), 406-417. https:/ / doi.org/ 10.1017/ S1466046611000408

Witzling, L., Wander, M., \& Phillips, E. (2011). Testing and educating on urban soil lead: A case of Chicago community gardens. Journal of A griculture, Food Systems, and C ommunity D evelopment, 1(2), 167-185.

https:/ / doi.org/ 10.5304/ jafscd.2010.012.015 


\section{Appendix}

\section{Interview Guide: Advancing Urban Agriculture Policy: Knowledge, Attitudes and Practices of Key Stakeholders}

\section{Purpose of the Study}

The purpose of this study is to understand decision makers' perspectives on how the city and province can use health evidence and public policy to better support urban agriculture. In this study, we would like to interview you, in your professional role, about how you use health evidence and public policies in your everyday professional practice. In addition, we would like to ask you about whether and how the results of a research project aimed at measuring, collecting and communicating the impacts of urban agriculture might be useful to you in your work.

\begin{tabular}{|c|c|c|}
\hline \multicolumn{3}{|l|}{ 1. Context } \\
\hline Construct & Question & Probes and cues \\
\hline Professional Practice & What is your professional role or title? & Tell me a bit about what you do. \\
\hline Role of Urban Agriculture & $\begin{array}{l}\text { How does your work relate to urban } \\
\text { agriculture in the City of Toronto? }\end{array}$ & \\
\hline Role of Policy & $\begin{array}{l}\text { Do you see your work as policy- } \\
\text { related? }\end{array}$ & $\begin{array}{l}\text { Can you give an example of how you } \\
\text { might typically work with policies? }\end{array}$ \\
\hline Role of Health Evidence & $\begin{array}{l}\text { Do you see your work as health- } \\
\text { related? }\end{array}$ & $\begin{array}{l}\text { Do you typically use health evidence in } \\
\text { your everyday work? If so, how? }\end{array}$ \\
\hline
\end{tabular}

\begin{tabular}{|l|l|l|}
\hline 2. Urban Agriculture Policy & \multicolumn{2}{|l|}{} \\
\hline Construct & Question & Probes and cues \\
\hline $\begin{array}{l}\text { Urban Agriculture as } \\
\text { Priority }\end{array}$ & $\begin{array}{l}\text { How important would you say urban } \\
\text { agriculture is in your daily work? }\end{array}$ & $\begin{array}{l}\text { How much of your time would you say } \\
\text { you spend on issues related to urban } \\
\text { agriculture? }\end{array}$ \\
& $\begin{array}{l}\text { Compared to all the other issues } \\
\text { facing Toronto, would you say urban } \\
\text { agriculture is considered a priority? }\end{array}$ & $\begin{array}{l}\text { How important is urban agriculture } \\
\text { compared with other things you work } \\
\text { on? }\end{array}$ \\
& $\begin{array}{l}\text { Do you see urban agriculture as } \\
\text { something that can support other } \\
\text { policy goals in Toronto? }\end{array}$ & $\begin{array}{l}\text {.... for you? ... for others you work with? } \\
\text { Con you give an example? }\end{array}$ \\
\hline $\begin{array}{l}\text { General impacts of urban } \\
\text { agriculture }\end{array}$ & $\begin{array}{l}\text { What do you see as the key benefits of } \\
\text { urban agriculture in Toronto? } \\
\text { What are the risks? }\end{array}$ & $\begin{array}{l}\text { Do you see any of these as health- } \\
\text { related? }\end{array}$ \\
\hline $\begin{array}{l}\text { Health impacts of urban } \\
\text { agriculture }\end{array}$ & $\begin{array}{l}\text { What do you see as the major health } \\
\text { impacts, positive or negative, of urban } \\
\text { agriculture in Toronto? }\end{array}$ & \\
\hline
\end{tabular}




\begin{tabular}{|c|c|c|}
\hline $\begin{array}{l}\text { Urban Agriculture Policy } \\
\text { Landscape }\end{array}$ & $\begin{array}{l}\text { To your understanding, what key } \\
\text { policies or institutions guide urban } \\
\text { agriculture activities in the City of } \\
\text { Toronto? }\end{array}$ & Who is involved? What do they do? \\
\hline $\begin{array}{l}\text { Urban Agriculture } \\
\text { Challenges and Risks }\end{array}$ & $\begin{array}{l}\text { What are the biggest challenges to } \\
\text { supporting urban agriculture in } \\
\text { Toronto? }\end{array}$ & $\begin{array}{l}\text { How well is the system working? Who } \\
\text { or what is not involved that should be? } \\
\text { How could municipal and/ or provincial } \\
\text { policy better support urban } \\
\text { agriculture? } \\
\text { Would health evidence help address } \\
\text { these challenges? How so? What kinds } \\
\text { of health evidence would be helpful? }\end{array}$ \\
\hline
\end{tabular}

\begin{tabular}{|l|l|l|}
\hline \multicolumn{3}{|l|}{ 3. Toronto Public Health (TPH) Indicators Project } \\
\hline Utility of Indicators & $\begin{array}{l}\text { Would having scientific evidence of } \\
\text { the public health impacts of urban } \\
\text { agriculture in Toronto help support } \\
\text { your work on urban agriculture? }\end{array}$ & $\begin{array}{l}\text { Which broad impacts are you most } \\
\text { interested in? }\end{array}$ \\
$\begin{array}{l}\text { Which non-health impacts are you } \\
\text { most interested in? }\end{array}$ \\
\hline TPH Indicators Project & $\begin{array}{l}\text { We are planning to develop indicators } \\
\text { to measure, assess, and communicate } \\
\text { the health impacts of urban } \\
\text { agriculture in Toronto. }\end{array}$ & $\begin{array}{l}\text { How do you think you might be able to } \\
\text { use that kind of health evidence in } \\
\text { your work? }\end{array}$ \\
& $\begin{array}{l}\text { Do you have any specific advice as to } \\
\text { how this type of project could help } \\
\text { meet your needs? I.e., What questions } \\
\text { could health evidence answer for you, } \\
\text { who could it help you convince, or } \\
\text { what format is most useful? }\end{array}$ \\
\hline $\begin{array}{l}\text { Future networks/ } \\
\text { relationships }\end{array}$ & $\begin{array}{l}\text { Do you think you might want to } \\
\text { continue working with Toronto Public } \\
\text { Health (or City of Toronto more } \\
\text { broadly) on issues of urban agriculture } \\
\text { in the future? }\end{array}$ & $\begin{array}{l}\text { What opportunities for collaboration or } \\
\text { networking do you see as having } \\
\text { potential? }\end{array}$ \\
\hline
\end{tabular}

